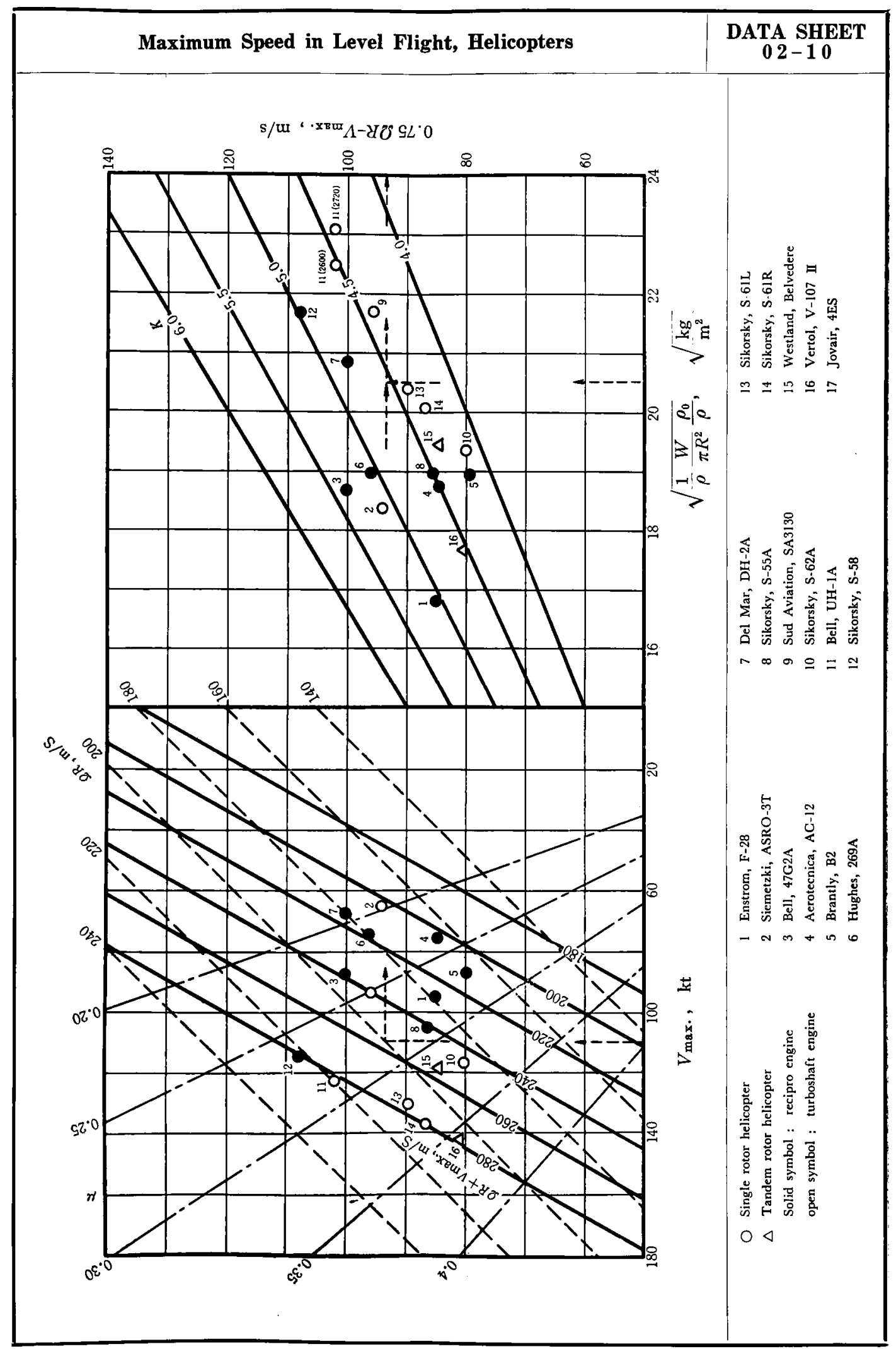




\section{DATA SHEET}

02-10

記号之単位

$$
\begin{aligned}
& W \cdots \cdot \text { 飛行重量, } \mathrm{kg} \\
& R \text { …ロー夕半径, } \mathrm{m} \\
& \sigma \cdots \cdot \text { ㄱ翼の solidity } \\
& \rho / \rho_{0} \cdots \text { 空気密度比 } \\
& V_{\max } \cdots \text { 最大速度 ; } k t
\end{aligned}
$$

\section{解 説}

ヘリコプタの水平最高速度は, 胴体その他の部分の 有害抗力パワが速度の 3 乘に比例して增加する (Data Sheet 02-08 参照)こともさることながら，主として つぎの 2 条件で制限を受けることになる.

［1］ロータ翼の前進側と後退側との揚力をバラン スするために必要なピッチ角の変化量が前進速度の增 大とともに增し，ついは後退翼の先端に近いところ で失速が起こる。

[2] ロー夕翼の前進側の先端における対空気相対 速度は回転による速度と前進速度との和であるから， この部分が最初に音速に近づき，マッ八数がある值に 達すると drag divergence を起こす。

これらはいずれもロータ翼の形状抗力パワを著るし く増すとともに，振動その他の理由で飛行を不可能に する．ロータ翼の空力特性を別にすれば，[1] が起こ る前進速度を高めるには $\Omega R$ を增せばよいが，[2]の 条件に不利となることはいうまでもない，実際のへリ コプタについて事情を調へるために簡単な解析を行な 3 .

\section{条件 [1]につて}

後退側の翼の先端付近の断面の代表として0.75R の断面を選ふことにすると，この断面の対気速度は誘 導速度を省略してつぎのように書ける。

$$
0.75 \Omega R-V_{\max }
$$

この部分の分担すべき揚力は単位面積当たり

$$
\Pi / \sigma \pi R^{2}
$$

に比例するものと考えてよいから，この断面の揚力係 数は,

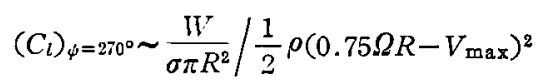

よって (3)を

$$
0.75 \Omega R-\Gamma_{\max }=K \sqrt{\frac{1}{\sigma} \frac{W}{\pi R^{2}} \frac{\rho_{0}}{\rho}}
$$

と書けば, $K$ は $\left(C_{l}\right)_{\psi=270^{\circ}}$ の平方根に逆比例する.

\begin{tabular}{|c|c|c|}
\hline 著 & 件 & $K$ \\
\hline K. D. WOOD ${ }^{13}$ & $\begin{array}{l}C_{Q} / C_{T}=0.30, \\
x_{\phi}=270^{\circ}=16^{\circ} \text { のと }\end{array}$ & 4.467 \\
\hline \multirow{2}{*}{ R. N. LIPTROT ${ }^{2)}$} & $\alpha_{\phi}=270^{\circ}=12^{\circ}$ のとき & 5.260 \\
\hline & $\alpha_{\phi=270^{\circ}}=16^{\circ}$ のと $\stackrel{\star}{\Xi}$ & 4.135 \\
\hline O.L.L. FITZWILLIAMS ${ }^{8}$ ) & 実㧱解析より & 4.320 \\
\hline K D. WOOD & 同上 & 4.217 \\
\hline
\end{tabular}
図表の右半分は（4）式を $K$ をパラメタとして描いた むのである. 断面のだしうる $C_{l}$ は失速によって制限 されるから $K$ には下限があることになる．実際のへ

\section{リコプタの水平最大速度}

$$
\begin{aligned}
& \Omega \cdots \cdots \text { タ回転数, rps } \\
& \mu \cdots \text {. tip speed ratio } \\
& \phi \cdot . \cdot \text { ロー夕翼の位嘈を示す角度 } \\
& \phi=0^{\circ} \text { は翼が飛行方向風下側にきた位置で， } \\
& \text { 回謓方向に測る. }
\end{aligned}
$$

リコプタのプロットからすると $K$ の值は 5.5 から 4.0 の範囲に撒布している。いろいろな研究者によっ て提案されている $K$ の設計值を下表に示す.

条件 [2]について

図表の左半分は縦軸に $\left(0.75 \Omega R-V_{\mathrm{max}}\right)$ ，横軸 に $V_{\max }$ をとったもので, 絽軸を $y$, 横軸を $x$ と書 けば，前進側ロー夕翼の先端速度は，

$$
\Omega R+V_{\max }=\frac{x+y}{0.75}+x
$$

あるいは,

$$
(1+0.75) x+y=0.75\left(\Omega R+V_{\max }^{r}\right)
$$

またロータの回転速度を先端の線速度で表わした

$$
\Omega R=\frac{x+y}{0.75}
$$

さらに tip speed ratio, $\mu$, は

$$
\mu=\frac{V_{\max }}{\Omega R}=\frac{0.75 x}{x+y}
$$

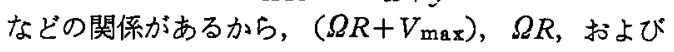
$\mu$ が一定の線はこの図表の上でいずれも直線となる. 前進側の先端マッ八数の限度は, 使用翼型および迎角, したがってロータ翼の提り下げなどによって変化する ことはもちろんであるが，現在普通に使用されている 翼型については 0.8 の程度と考えられている ${ }^{5)}$.

\section{交 献}

1) K.D. WOoD, Aersdynamic Design of Helicopters, IAS Preprint $517(1 / 1955)$

2) R.N. Liptrot, An Analysis of NACA Helicopter Reports, A. R. C. C. P. No. 183 (1954)

3) O. L. L. Fitzwilliams, The Giant Helicopter, J. Helicopter Ass, G. B., 5, 4, (1 5/1952)

4) K. D. Wood, Airplane Design.

5) I. Sikorsky, Aersdynamic Parameters Selection in Helicopter Design, J. Am. Heli. Soc., 5, 1 (1/1960) 


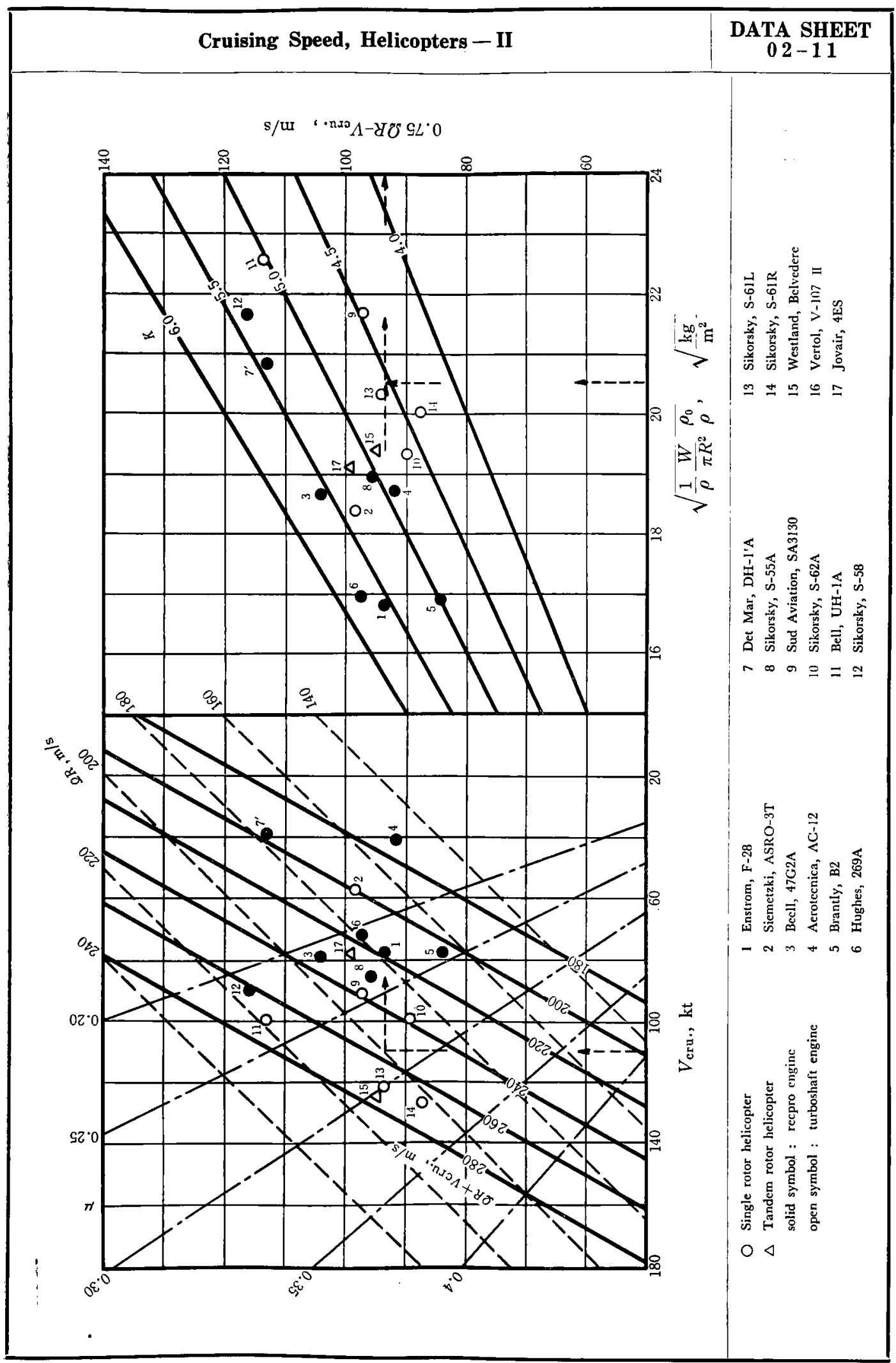




\begin{tabular}{|c|c|}
\hline $\begin{array}{c}\text { DATA SHEET } \\
02-11\end{array}$ & リコプタの巡航速度－II \\
\hline 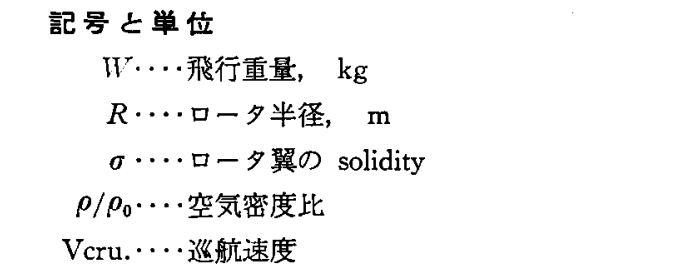 & $\begin{array}{l}\Omega \cdots \text { ・ータ回転数, rps } \\
\mu \cdots \text { tip speed ratio }\end{array}$ \\
\hline $\begin{array}{l}\text { 解 説 } \\
\text { DATA SHEET 02-09 に扎てて, パワの経済とい } \\
\text { う見方から最適巡航速度を眺めたが, 本図表は DATA } \\
\text { SHEFT 02-10 と同様にロー夕翼の空気力学の見地か } \\
\text { らへリコプタの巡航速度を調べたものである. 実在の } \\
\text { 機体のプロットからみると } K \text { の值は } 4.3 \sim 5.8 \text {, 前進 }\end{array}$ & 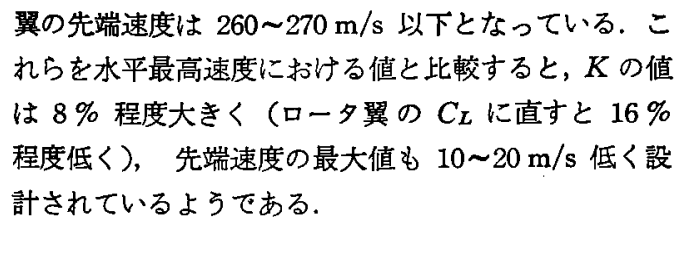 \\
\hline
\end{tabular}

